\title{
INTERACTIVE LEARNING DALAM PEMBELAJARAN SPEAKING DI KELAS V SEKOLAH DASAR
}

\author{
Dudu Suhandi Saputra \\ d.suhandi.s@gmail.com
}

\begin{abstract}
ABSTRAK
Penelitian ini bertujuan guna mengetahui efektivitas dari penerapan interactive learning dalam meningkatkan hasil belajar siswa pada pembelajaran bahasa Inggris di kelas V Sekolah Dasar Negeri Cileunyi 02 kecamatan Cileunyi Kabupaten Bandung. Penelitian Tindakan Kelas pada Siswa Kelas V dilakukan di Sekolah Dasar Negeri Cileunyi 02 Kecamatan Cileunyi, Kabupaten Bandung. Instrumen yang digunakan dalam penelitian ini adalah pedoman observasi, pedoman wawancara, catatan lapangan, lembar penilaian proses, dan rekaman poto. Data diperoleh, dianalisis, dan direfleksi dengan menggunakan metode deskripsi kualitatif. Dapat ditarik kesimpulan dalam penerapan pembelajaran interactive learning di kelas $\mathrm{V}$ Sekolah Dasar Negeri Cileunyi 02 telah berhasil menciptakan suasana belajar yang dapat meningkatkan minat belajar siswa sekaligus menciptakan suasana belajar menyenangkan dan bermakna bagi siswa. Berdasarkan hasil penelitian siklus I, II, dan III. Pada siklus I kemampuan siswa masih rendah, siswa masih malu-malu, takut, dan ragu-ragu dalam memperagakan dialog sederhana secara berpasangan didepan kelas. Nilai rata-rata untuk siklus I adalah 46.97. Pada siklus II kemampuan siswa mulai mengalami peningkatan, terlihat dari hasil nilai rata-rata pada siklus II adalah 65.15. Pada siklus III kemampuan siswa dalam pembelajaran speaking menggunakan interactive learning dengan teknik role playing semakin meningkat, terlihat dari hasil nilai rata-rata pada siklus III adalah 85.23. Hal ini menunjukan bahwa interactive learning dengan menggunakan teknik role playing dapat meningkatkan proses serta hasil belajar siswa dalam pembelajaran speaking.
\end{abstract}

Kata kunci: interactive learning, speaking 


\section{PENDAHULUAN}

Bahasa dalam kehidupan manusia sangat memiliki peranan yang sentral. Malalui bahasa, manusia bisa melakukan hubungan sosial dengan optimal, bisa mengikuti perkembangan jaman dengan optimal. Zaman globalisasi seperti sekarang ini, sangat menuntut seluruh manusia untuk bisa menerima perkembangan yang terjadi dengan sangat cepat. Perkembangan yang terjadi sangat pesat di antaranya dalam bidang ilmu pengetahuan. Sejalan dengan hal tersebut bahasa yang digunakan pun akan semakin bervariasi. Bahasa yang digunakan sebagai bahasa internasional adalah bahasa Inggris. Oleh sebab itu, di Indonesia sendiri pembelajaran bahasa Inggris sudah mulai diterapkan di sekolah dasar.

Kebijakan dimungkinkannya pelajaran bahasa Inggris di Sekolah Dasar secara resmi dilandasi dengan SK Menteri Pendidikan dan Kebudayaan No. 060/U/1993 tanggal 25 Februari 1993 (Tuti: 2009 e-refleksi.yk-edu.org) tentang ,dimungkinkannya program bahasa Inggris sebagai mata pelajaran muatan lokal Sekolah Dasar, dan dapat dimulai pada kelas empat Sekolah Dasar. Pembelajaran bahasa Inggris terintegrasi dalam empat keterampilan berbahasa diantaranya listening, speaking, reading dan writing. Salah satu keterampilan berbahasa yang cukup kompleks adalah speaking. Keterampilan berbicara dalam bahasa Inggris merupakan suatu keterampilan bahasa yang perlu dikuasai dengan baik, karena keterampilan ini merupakan suatu indikator terpenting bagi keberhasilan siswa dalam belajar bahasa. Melalui penguasaan keterampilan berbicara yang baik, siswa dapat mengkomunikasikan ide mereka baik di sekolah maupun dengan penutur asing.

Namun dalam kenyataan, pembelajaran speaking memiliki berbagai hambatan. Berdasarkan data di lapangan dalam hal ini penulis mengambil salah satu contoh kasus di Sekolah Dasar, dimana para siswa sering mengalami kesulitan dalam pembelajaran speaking dikarenakan mereka belum begitu menguasai pronounciation dan vocabulary dalam bahasa Inggris. Selain itu, siswa juga merasa kurang percaya diri untuk mencoba berkomunikasi dengan menggunakan bahasa Inggris. Berdasarkan data di lapangan, siswa kelas V SD Negeri Cileunyi 02 pada umumnya sudah bisa berinteraksi dengan lancar antara yang satu dengan yang lainnya. Akan tetapi hanya sebatas menggunakan bahasa Indonesia saja, mereka belum mampu dan belum bisa menggunakan bahasa Inggris. Walaupun mata pelajaran bahasa Inggris merupakan mata pelajaran muatan lokal di SD Negeri Cileunyi 02 yang bersifat wajib diikuti oleh seluruh siswa, namun sebagian dari mereka masih menganggap bahwa bahasa Inggris merupakan bahasa asing yang tidak perlu dipelajari.

Berdasarkan data tersebut, penulis berusaha mematahkan pandangan mereka dan berupaya untuk mencari alternatif sebagai upaya dalam meningkatkan kemampuan berbicara siswa. Salah satu metode pembelajaran yang dapat dijadikan sebagai alternatif adalah metode interactive learning. Konsep ini menekankan pada pandangan bahasa, tentang pembelajaran, dan orang-orang yang terlibat atau dalam arti lain disebut dengan pola interaksi. Orang dewasa 
dalam hal ini guru, berkewajiban untuk menyediakan lingkungan yang menunjang untuk siswa.

\section{METODE PENELITIAN}

Penelitian dilaksanakan di kelas $\mathrm{V}$ SDN Cileunyi 02 Kecamatan Cileunyi Kabupaten Bandung. Metode yang digunakan dalam penelitian ini yaitu metode penelitian tindakan kelas. Model penelitian tindakan kelas (PTK) yang digunakan dalam penelitian ini adalah model penelitian tindakan kelas berdasarkan teori John Elliot. Model ini pada setiap siklusnya terdiri terdiri dari beberapa aksi, yaitu antara tiga sampai lima aksi (tindakan). Tindakan ini diambil berdasarkan pemikiran bahwa dalam suatu mata pelajaran terdapat beberapa pokok bahasan dan setiap pokok bahasan terdiri atas beberapa materi yang tidak dapat diselesaikan dalam satu kali tindakan.” Sementara itu, setiap tindakan terdiri dari beberapa langkah yang terealisasi dalam bentuk kegiatan belajar-mengajar.

Alasan penulis menggunakan desain Penelitian Tindakan Kelas yaitu karena adanya kesamaan karakteristik yang terdapat dalam PTK dengan masalah yang ada. Adapun masalah yang akan diteliti yaitu mengenai kemampuan speaking dalam pembelajaran bahasa Inggris di Sekolah Dasar. Metode pengumpulan data pada penelitian ini dilakukan dengan observasi proses belajar mengajar dan tes. Hasil penelitian dari setiap siklus dan tindakan dideskripsikan, dianalisis, dan direfleksikan untuk mengetahui kelebihan dan kekurangan dalam kegiatan pembelajaran yang ditujukan untuk perbaikan pelaksanaan tindakan dan pembelajaran selanjutnya. Secara rinci pelaksanaan tindakan pada setiap siklus dapat diuraikan sebagai berikut.

\section{HASIL PENELITIAN}

\section{Siklus I}

Penelitian Siklus I tindakan 1 dilaksanakan pada hari Kamis, 14 Maret 2011 dan siklus 1 tindakan 2 dilaksanakan pada tangga 7 April 2011 pukul 07.00 sampai $08.10 \mathrm{WIB}$ di kelas V SDN Cileunyi 02 Kecamatan Cileunyi Kabupaten Bandung dengan tema "sports". Jumlah siswa yang hadir pada penelitian Siklus I Tindakan 1 sebanyak 33 orang. Pada pelaksanaan penelitian ini, penulis menggunakan pendekatan interactive, metodeinteractive learning, serta menggunakan teknik role playing. Adapun uraian dari pelaksanaan penelitian Siklus I adalah sebagai berikut:

Berdasarkan pada data serta temuan yang penulis dapatkan di lapangan pada siklus I tindakan 1 dan 2 dalam kegiatan speaking secara berpasangan, yakni pada saat siswa melakukan kegiatan speaking ada beberapa orang siswa yang sangat antusias dalam mengucapkan bahasa Inggris, walaupun masih terdapat kekurangan dalam pengucapannya. Namun ada pula beberapa orang siswa lainnya yang merasa kurang percaya diri dan kesulitan dalam mengucapkan kata dalam bahasa Inggris sehingga pengucapannya pun masih kurang baik. Siswa juga masih merasa bingung ketika diminta untuk mempraktekan dialog sederhana secara berpasangan, dan ada beberapa siswa lainnya yang masih belum bersungguh-sungguh dalam mempraktekan dialog sederhana tersebut. 
Pada tahap proses penilaian proses, masih banyak siswa yang mengalami kesulitan serta ragu-ragu dalam memperagakan dialog berpasangan didepan kelas. Bahkan ketika guru melakukan penilaian proses pada saat praktek speaking, banyak siswa yang mengganggu konsentrasi siswa lain. Selain itu masih ada beberapa orang siswa beberapa orang yang belum tahu nama-nama jenis olahraga dalam bahasa Inggris. Dalam memperagakan dialog sederahana secara berpasangan, mereka masih harus membaca dengan bantuan tulisan atau teks dialog.

Berdasarkan hasil penelitian pada siklus I tindakan 1 dan 2 ini diperoleh nilai secara individu pada saat pembelajaran dengan menggunakan interactive learning. Pada siklus I tindakan 1 dan 2 ini masih banyak siswa yang mengalami kesulitan dalam mempraktekan speaking dengan penerapan yang baru, karena siswa tersebut masih merasa malu-malu, takut, ragu-ragu, dan masih ada juga yang mengganggu temannya yang sedang melakukan tes proses speaking sehingga siswa sulit dalam mengungkapkan dan mengucapkan kalimat sederhana yang mereka pelajari. Berdasarkan hasil penelitian pada siklus I tindakan 1 dan 2 , pada tahap pronunciation (pengucapan) guru melakukan penilaian proses dengan cara siswa diminta untuk menyebutkan nama-nama jenis olahraga dalam bahasa Inggris.

Berdasarkan hasil tes kemampuan berbicara maka analisis nilai untuk pronunciation (pengucapan) sebagai berikut: 5 orang siswa $(15.15 \%)$ dengan tingkat pronunciation beberapa kesalahan fonemik, tekanan dan tetapi pesan yang disampaikan dapat dipahami. 22 orang siswa $(66.67 \%)$ dengan tingkat pronunciation sering terjadi kesalahan fonemik, tekanan, dan intonasi yang menyebabkan pesan kadang-kadang tidak tersampaikan. 3 orang siswa (18.18\%) dengan tingkat pronunciation sering terjadi kesalahan fonemik, tekanan, dan intonasi yang menyebabkan pesan tidak tersampaikan.

Pada tahap penilaian fluency, guru meminta siswa untuk memperagakan dialog sederhana secara berpasangan didepan kelas. Berdasarkan hasil penilaian proses pada aspek fluency (kelancaran) maka diperoleh nilai sebagai berikut: 5 orang siswa (15.15\%) dengan tingkat fluency beberapa perhentian yang tidak seperti penutur asli masih terjadi tetapi tidak mengganggu keterpahaman. 16 orang siswa $(48.48 \%)$ dengan tingkat fluency banyak terjadi perhentian yang bukan seperti pada penutur asli sehingga mengganggu keterpahaman. 12 orang siswa $(36.36 \%)$ dengan tingkat fluency ujaran kadang patah-patah atau aksen sangat asing sehingga keterpahaman sulit terjadi. Jika dilihat dari nilai secara keseluruahan maka dapat disimpulkan nilai rata-rata kelas pada siklus I tindakan 1 dan 2 adalah 46.97. Nilai rata-rata kelas tersebut masih kurang dari KKM untuk mata pelajaran bahasa Inggris di SDN Cileunyi 02 yaitu 60, Jika dilihat berdasarkan standar mastery learning nilai rata-rata tersebut belum dinyatakan tuntas belajar karena belum berada di atas standar mastery learning yang berkisar pada nilai 75. Sedangkan jika dilihat secara perorangan terdapat empat $(12,12 \%)$ siswa berada di dalam standar mastery learning yaitu 75, 29 (87,88\%) 
siswa berada di bawah standar mastery learning.

Pada pembelajaran siklus I tindakan 1 dan 2 ini, dirasa masih banyak siswa yang mengalami kesulitan, grogi, malumalu, dan masih takut untuk mengemukakan pendapatnya. Sehingga pencapaian hasil belajar masih rendah. Maka dari itu penulis mempunyai data sementara siswa yang mengalami kesulitan perlu mendapatkan perhatian, bimbingan dan arahan dari penulis agar hasil yang diperoleh lebih baik dari pada pembelajaran sebelumnya.

Dalam pembelajaran dengan menggunakan interactive learning melalui teknik role playing ini, hasil penilaian, proses observasi, wawancara, dan catatan lapangan dijadikan bahan pertimbangan dalam merencanakan dan menentukan tindakan selanjutnya. Pada siklus I tindakan 1 dan 2 ini masih banyak siswa yang mengalami kesulitan dalam praktek speaking yang telah ditentukan karena merasa malu, takut dan juga ragu. Pada siklus I ini ada juga siswa yang terlihat kurang antusias. Beberapa siswa masih ada yang kurang aktif dalam proses belajar, siswa masih mengalami kesulitan, merasa dan belum berani. Dari beberapa faktor tersebut maka interactive learning belum mampu membuat situasi belajar yang menyenangkan dan bermakna bagi siswa, maka dengan melihat kekurangan dari pembelajaran siklus I tindakan 1 dan 2 tersebut, penulis beranggapan perlu adanya tindakan perbaikan pada pembelajaran berikutnya (Siklus II tindakan 1 dan 2).

Adapun tindakan yang akan diambil oleh penulis guna perbaikan pada pembelajaran selanjutnya diantaranya adalah dengan memberikan motivasi belajar kepada seluruh siswa, membangkitkan rasa percaya diri setiap siswa dengan jalan melakukan pendekatan baik itu pendekatan individual maupun pendekatan secara menyeluruh, serta memberitahukan materi yang akan dipelajari pada pembelajaran selanjutnya dengan tujuan supaya setiap siswa mempersiapkan atau mencari sendiri tentang pokok bahasan yang akan dipelajari pada pembelajaran selanjutnya. Berdasarkan beberapa rencana tindakan perbaikan tersebut, penulis berharap adanya peningkatan motivasi serta hasil belajar siswa pada kegiatan pembelajaran selanjutnya.

\section{Siklus II}

Penulis melaksanakan penelitian Siklus II tindakan 1 pada hari Kamis, 7 April 2011 sedangkan untuk tindakan 2 dilaksanakan pada hari Kamis, 14 April 2011 pukul 07.00 sampai 08.10 WIB di kelas V SDN Cileunyi 02 Kecamatan Cileunyi Kabupaten Bandung dengan tema "on the weekend". Jumlah siswa yang hadir pada penelitian Siklus II Tindakan 1 sebanyak 33 orang. Pada pelaksanaan penelitian ini, penulis menggunakan pendekatan interactive, metode interactive learning, serta menggunakan teknik role playing. Adapun uraian dari pelaksanaan penelitian Siklus II adalah sebagai berikut:

Berdasarkan pada data serta temuan yang penulis dapatkan di lapangan pada siklus II tindakan 1 dan 2 dalam kegiatan speaking secara berpasangan, yakni sudah tampak adanya perubahan dari kegiatan pembelajaran sebelumnya (pada siklus I tindakan 1 dan 2) perubahan 
tersebut diantaranya siswa sudah mulai merasa percaya diri dalam memperagakan dialog sederhana tentang on the weekend. Akan tetapi masih ada Siswa yang merasa bingung ketika diminta untuk mempraktekan dialog sederhana secara berpasangan, dan ada beberapa siswa lainnya yang masih belum bersungguh-sungguh dalam mempraktekan dialog sederhana tersebut.

Pada tahap proses penilaian proses, sudah ada perubahan pada diri siswa itu sendiri yang diantaranya siswa mulai merasa apercaya diri untuk memeragakan dialog didepan kelas, siswa sudah mulai terfokus dalam mempergakan dialog. Akan tetapi masih ada beberapa orang siswa yang masih mengalami kesulitan serta ragu-ragu dalam memperagakan dialog berpasangan didepan kelas tersebut.

Berdasarkan hasil penelitian pada siklus II tindakan 1 dan 2 ini diperoleh nilai secara individu pada saat pembelajaran dengan menggunakan interactive learning. Pada siklus II tindakan 1 dan 2 ini masih ada beberapa orang siswa yang mengalami kesulitan dalam mempraktekan speaking dengan penerapan yang baru, karena siswa tersebut masih merasa malu-malu, takut, ragu-ragu. Berdasarkan hasil penelitian pada siklus II tindakan 1 dan 2, pada tahap pronunciation (pengucapan) guru melakukan penilaian proses dengan cara siswa diminta untuk menyebutkan namanama jenis olahrag dalam bahasa Inggris. Berdasrkan hasil tes proses tersebut, maka diperoleh nilai sebagai berikut: 6 orang siswa (18.18\%) dengan tingkat pronunciation (pengucapan) yang sangat bagus, 17 orang siswa (51.52\%) dengan tingkat pronunciation terjadi beberapa kesalahan fonemik, tekanan dan tetapi pesan yang disampaikan dapat dipahami. 10 orang siswa $(30.30 \%)$ dengan tingkat pronunciation (pengucapan) sering terjadi kesalahan fonemik, tekanan, dan intonasi yang menyebabkan pesan kadang-kadang tidak tersampaikan. 0 orang siswa $(00.00 \%)$ dengan tingkat pronunciation sering terjadi kesalahan fonemik, tekanan, dan intonasi yang menyebabkan pesan tidak tersampaikan. Penilaian proses pada aspek fluency (kelancaran) maka diperoleh nilai sebagai berikut: 13 orang siswa (39.39\%) dengan tingkat fluency beberapa perhentian yang tidak seperti penutur asli masih terjadi tetapi tidak mengganggu keterpahaman. 18 orang siswa $(54.55 \%)$ dengan tingkat fluancy banyak terjadi perhentian yang bukan seperti pada penutur asli sehingga mengganggu keterpahaman. 2 orang siswa $(6.06 \%)$ dengan tingkat fluency ujaran kadang patah-patah atau aksen sangat asing sehingga keterpahaman sulit terjadi.

Nilai rata-rata kelas pada siklus II tindakan 1 dan 2 adalah 65.15. Nilai ratarata kelas tersebut sudah lebih dari KKM untuk mata pelajaran bahasa Inggris di SDN Cileunyi 02 yaitu 60 sehingga pada pembelajaran siklus II tindakan 1 dan 2 dirasa adanya peningkatan hasil belajar siswa, jika dilihat berdasarkan standar mastery learning nilai rata-rata tersebut belum dinyatakan tuntas belajar karena belum berada di atas standar mastery learning yang berkisar pada nilai 75 . Sedangkan jika dilihat secara perorangan terdapat enam $(18,18 \%)$ siswa berada di atas standar mastery learning, tujuh $(21,21 \%)$ siswa berada di dalam standar mastery learning yaitu 75, 20 (60,61\%) berada di bawah standar mastery 
learning. Pada pembelajaran siklus II tindakan 1 dan 2 ini, masih ada beberapa orang siswa yang mengalami kesulitan, grogi, malu-malu, dan masih takut untuk mengemukakan pendapatnya. Sehingga pencapaian hasil belajar individu ada yang masih rendah. Maka dari itu penulis mempunyai data sementara siswa yang mengalami kesulitan masih perlu mendapatkan perhatian, bimbingan dan arahan dari penulis agar hasil yang diperoleh lebih baik dari pada pembelajaran sebelumnya.

Pada siklus II tindakan 1 dan 2 ini masih ada beberapa orang siswa yang mengalami kesulitan dalam praktek speaking yang telah ditentukan karena merasa malu, takut dan juga ragu. Pada siklus II ini ada juga beberapa orang siswa yang terlihat masih kurang antusias. Beberapa siswa masih ada yang kurang aktif dalam proses belajar, siswa masih mengalami kesulitan, merasa malu, takut dan belum berani. Dari beberapa faktor tersebut maka interactive learning belum mampu membuat situasi belajar yang menyenangkan dan bermakna bagi siswa.

Adapun tindakan yang akan diambil oleh penulis guna perbaikan pada pembelajaran selanjutnya diantaranya adalah dengan terus menerus memberikan motivasi belajar kepada siswa yang masih mengalami kesulitan dalam mengikuti pembelajaran speaking, membangkitkan rasa percaya diri setiap siswa dengan jalan melakukan pendekatan baik itu pendekatan individual maupun pendekatan secara menyeluruh, serta memberitahukan materi yang akan dipelajari pada pembelajaran selanjutnya dengan tujuan supaya setiap siswa mempersiapkan atau mencari sendiri tentang pokok bahasan yang akan dipelajari pada pembelajaran selanjutnya. Berdasarkan beberapa rencana tindakan perbaikan tersebut, penulis berharap adanya peningkatan motivasi serta hasil belajar siswa pada kegiatan pembelajaran selanjutnya.

\section{Siklus III}

Penulis melaksanakan penelitian Siklus III tindakan 1 Kamis, 21 April 2011 sedangkan siklus III tindakan 2 dilakukan Kamis, 28 April 2011 pukul 07.00 sampai 08.10 WIB di kelas V SDN Cileunyi 02 Kecamatan Cileunyi Kabupaten Bandung dengan tema "part of the body". Jumlah siswa yang hadir pada penelitian Siklus III Tindakan 1 sebanyak 33 orang. Pada pelaksanaan penelitian ini, penulis menggunakan pendekatan interactive, metode interactive learning, serta menggunakan teknik role playing. Adapun uraian dari pelaksanaan penelitian Siklus III adalah sebagai berikut:

Berdasarkan pada data serta temuan yang penulis dapatkan di lapangan pada siklus III tindakan 1 dan 2 dalam kegiatan speaking secara berpasangan, yakni pada saat siswa melakukan kegiatan speaking siswa sangat antusias dalam mengucapkan bahasa Inggris, walaupun masih terdapat kekurangan dalam pengucapannya. Namun ada pula beberapa orang siswa lainnya yang merasa kurang percaya diri dan kesulitan dalam mengucapkan kata dalam bahasa Inggris sehingga pengucapannya pun masih kurang baik. Siswa juga masih merasa bingung ketika diminta untuk mempraktekan dialog sederhana secara berpasangan, dan semua siswa 
bersungguh-sungguh mempraktekan dialog sederhana tersebut.

Berdasarkan hasil penelitian pada siklus I tindakan 1 dan 2 ini diperoleh nilai secara individu pada saat pembelajaran dengan menggunakan interactive learning. Pada siklus III tindakan 1 dan 2 siswa sudah merasa percaya diri dalam mempraktekan speaking, Berdasarkan hasil penelitian pada siklus III tindakan 1 dan 2, pada tahap pronunciation (pengucapan) guru melakukan penilaian proses dengan cara siswa diminta untuk menyebutkan namanama jenis olahrag dalam bahasa Inggris. Berdasrkan hasil tes proses tersebut, maka diperoleh nilai sebagai berikut: 20 orang siswa (60.61\%) dengan tingkat pronunciation yang sangat bagus, 13 orang siswa (39.39\%) dengan tingkat pronunciation terdapat beberapa kesalahan fonemik, tekanan dan tetapi pesan yang disampaikan dapat dipahami. 0 orang siswa $(0.00 \%)$ dengan tingkat pronunciation sering terjadi kesalahan fonemik, tekanan, dan intonasi yang menyebabkan pesan kadang-kadang tidak tersampaikan. 0 orang siswa $(0.00 \%)$ dengan tingkat pronunciation sering terjadi kesalahan fonemik, tekanan, dan intonasi yang menyebabkan pesan tidak tersampaikan.

Berdasarkan hasil penilaian maka analisis nilai untuk fluency (kelancaran) sebagai berikut: 8 orang siswa $(24.24 \%)$ dengan tingkat fluency yang sangat bagus, 24 orang siswa $(72.73 \%)$ dengan tingkat fluency beberapa perhentian yang tidak seperti penutur asli masih terjadi tetapi tidak mengganggu keterpahaman. 1 orang siswa $(3.03 \%)$ dengan tingkat fluency banyak terjadi perhentian yang bukan seperti pada penutur asli sehingga men gganggu keterpahaman. 0 orang siswa $(0.00 \%)$ dengan tingkat fluency ujaran kadang patah-patah atau aksen sangat asing sehingga keterpahaman sulit terjadi. Pada penilaian proses speaking (berbicara) tersebut, maka diperoleh nilai individu secara keseluruhan dan nilai rata-rata kelas pada pembelajaran siklus III tindakan 1 dan 2 adalah sebagai berikut: nilai rata-rata kelas pada siklus III tindakan 1 dan 2 adalah 85.23. Nilai rata-rata kelas tersebut sudah lebih dari KKM untuk mata pelajaran bahasa Inggris di SDN Cileunyi 02 yaitu 60 sehingga pada pembelajaran siklus III tindakan 1 dan 2 dirasa adanya peningkatan hasil belajar siswa.

Pada tahap proses penilaian proses, siswa sudah merasa percaya diri dalam memperagakan dialog berpasangan didepan kelas. Bahkan ketika guru melakukan penilaian proses pada saat praktek speaking, siswa sudah terfokus untuk memperagakan dialog sederhana tersebut. Dapat disimpulkan Pada pembelajaran siklus III tindakan 1 dan 2 ini, dirasa banyak siswa yang mengalami Peningkatan hasil belajar serta mereka sudah tidak merasa ragu-ragu lagi untuk mengemukakan pendapatnya. Sehingga pencapaian hasil belajar meningkat. Hal tersebut dapat dilihat dari hasil nilai ratarata kelas pada siklus III tindakan 1 dan 2 yaitu 85,23. Nilai rata-rata kelas tersebut sudah lebih dari KKM untuk mata pelajaran bahasa Inggris di SDN Cileunyi 02 yaitu 60, Jika dilihat berdasarkan standar mastery learning nilai rata-rata tersebut sudah dinyatakan memenuhi standar mastery learning (belajar tuntas). Akan tetapi jika dilihat secara perorangan terdapat $19(57,58 \%)$ siswa berada di dalam standar mastery learning yaitu 75 , 
$14(42,42 \%)$ siswa berada pada standar mastery learning.

Pada siklus III ini siswa terlihat sangat antusias. Siswa sudah mulai aktif dalam proses belajar, siswa tidak lagi mengalami kesulitan, merasa lebih percaya diri dan berani. Dari beberapa faktor tersebut maka interactive learning mampu membuat situasi belajar yang menyenangkan dan bermakna bagi siswa, maka dengan melihat peningkatan dari pembelajaran siklus III tindakan 1 dan 2 tersebut, penulis beranggapan bahwa pembelajaran speaking sangat cocok dengan menggunakan metode interactive learning dengan teknik role playing.

Berdasarkan hasil pengamatan dalam pembelajaran speaking menggunakan interactive learning dengan teknik role playing terdapat peningkatan hasil pembelajaran siswa maupun kegiatan pembelajaran itu sendiri. Hal itu juga dapat dilihat dari tes proses didapat oleh siswa yang mengalami peningkatan yang cukup baik dari siklus I sampai siklus III yang telah penulis paparkan sebelumnya.

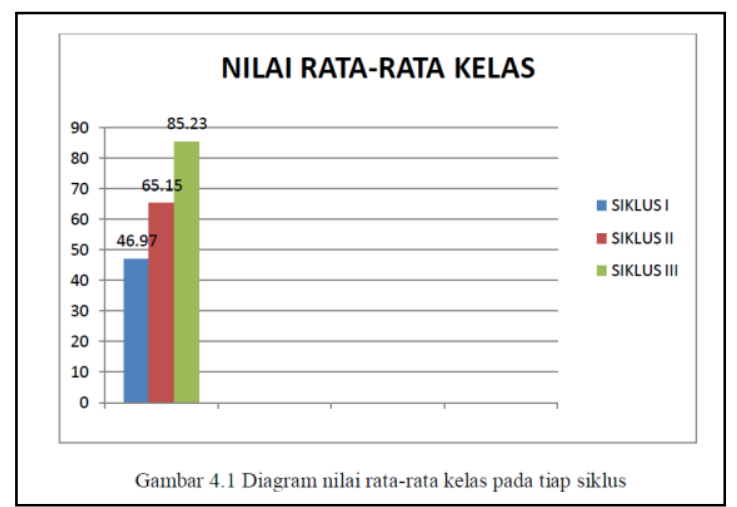

Berdasarkan diagram diatas dapat dilihat bahwa nilai rata-rata hasil belajar siswa pada setiap siklusnya cendrung meningkat. Pada hasil pembelajaran siklus I nilai rata-rata kelas baru mencapai 46.97 nilai tersebut masih jauh dari KKM untuk mata pelajaran bahasa Inggris di SDN Cileunyi 02. Hasil belajar pada pembelajaran siklus I tersebut masih dianggap kurang, keaadaan ini disebabkan oleh beberapa faktor yang mempengaruhi kegiatan pembelajaran yang diantaranya dari segi siswa yang merasa tidak percaya diri dalam memperagakan dialog sederhana secara berpasangan di depan kelas, siswa belum begitu antusias dalam mengikuti pembelajaran speaking, siswa merasa kesulitan dalam pengucapan kata dalam bahasa Inggris.

Pada hasil pembelajaran siklus II nilai rata-rata kelas mencapai 65.15 , rata-rata nilai tersebut sudah lebih dari KKM mata pelajaran bahasa Inggris SDN Cileunyi 02. Hasil belajar pada pembelajaran siklus II tersebut sudah ada peningkatan yang cukup bagus dibanding dengan hasil pembelajaran sebelumnya. Hal ini disebabkan oleh beberapa factor yang mempengaruhi peningkatan hasil belajar siswa itu sendiri yang dianataranya siswa sudah mulai merasa percaya diri dalam memperagakan dialog sederhana secara berpasangan didepan kelas, siswa sudah mulai focus pda pembelajaran, dan siswa mulai antusian dalam mengikuti pembelajaran speaking. Namun disamping factor-faktor yang mempengaruhi peningkatan hasil belajar siswa tersebut, terdapat pula factor dari segi guru dan materi pembelajaran yang dapat mempengaruhi peningkatan hasil belajar itu sendiri. Pada pembelajaran siklus II ini guru telah melakukan tindakan perbaikan dari pembelajaran sebelumnya. Tindakan-tindakan perbaikan tersebut diantara guru melakukan pendekatan baik secara individu maupun secara menyeluruh 
terhadap siswa, guru memberikan motivasi belajar kepada siswa, dan guru memilih materi yang sesuai dengan keadaan kondisi siswa itu sendiri.

Nilai rata-rata hasil pembelajaran pada siklus III mencapai 85.23 , nilai rata-rata tersebut sudah diatas KKM pelajaran bahasa Inggris SDN Cileunyi 02. Berdasarkan peningkatan hasil belajar siswa pada pembelajaran siklus III tersebut penulis beranggapan bahwa hasil pembelajaran siklus III sangat memuaskan, adapunn factor-faktor yang mendukung terjadinya peningkatan hasil belajar tersebut diantaranya dari factor siswa serta dari factor guru itu sendiri disamping terdapat factor lingkungan yang dapat mempengaruhi semua peningkatan hasil belajar siswa tersebut.

Berdasarkan hasil penilaian proses yang dilakukan penulis pada saat pembelajaran siklus I, II, dan III terdiri dari dua aspek penilaian diantaranya aspek pronunciation (pengucapan), dan fluency (kelancaran). Dari kedua aspek penilaian tersebut mengalami peningkatan hasil pada setiap siklusnya, adapun aspek yang peningkatannya sangat bagus pada setiap siklusnya adalah pada aspek pronunciation (pengucapan) hal ini diakibatkan oleh beberapa factor pendunkung yang dapat mempengaruhi peningkatan tersebut. Factor-faktor pendukung tersebut diantaranya dari segi siswa itu sendiri, guru, bahan ajar, serta factor lingkungan itu sendiri. Factor-faktor pendukung tersebut saling berhungan antara satu sama lain, disamaping itu juga penulis memilih serta melakukan tindakan perbaikan pada setiap pembelajaran yang bertujuan untuk membuat situasi belajar yang menyenangkan dan bermakna bagi siswa khususnya pada pembelajaran speaking (berbicara).

Berdasarkan pada temuan-temuan esensial yang dikemukakan pada bagian pembahasan, maka penulis dapat melakukan sintesis dan konfirmasi terhadap hasil temuan esensial tersebut, berkaitan dengan kajian teoritis yang telah diuraikan pada bab II dan literatur lain. Pembelajaran speaking yang dilaksanakan oleh penulis menerapkan interactive learning untuk proses kegiatan penelitian ini. Adapun tahapan pembelajaran yang dilakukan penulis dengan menggunakan interactive learning melalui teknik role playing diantaranya: 1) Pronuntiation (pelafalan), 2) perbaikan, 3) praktek lisan.

\section{SIMPULAN}

1. Penerapan interactive learning dengan menggunakan teknik role playing dapat memberikan hasil yang positif dengan memnciptakan suasana belajar yang efektif dan kondusif, dan bermakna bagi siswa.

2. Penerapan interactive learning dengan menggunakan teknik role playing ini dapat meningkatkan hasil belajar siswa pada pembelajaran speaking. Hal tersebut dapat dilihat dari meningkatnya kemampuan speaking siswa pada setiap siklus. Pada siklus I nilai hasil tes proses siswa rata-rata 46.97 , nilai rata-rata pada siklus II yaitu 65.15 , nilai ratarata siklus III yaitu 85.23 ini berarti nilai rata-rata hasil belajar siswa pada pembelajaran speaking dari 
siklus II hingga siklus III mengalami peningkatan sebesar $38.26 \%$.

\section{REKOMENDASI}

Berdasarkan kajian teoritis dan tamuan hasil penelitian yang diperoleh penulis, maka dapat dikemukakan beberapa rekomendasi dalam meningkatkan aktivitas dan kemampuan speaking siswa kelas V Sekolah Dasar dengan menggunakan interactive learning denga teknik role playing, yaitu: Guru kelas harus berani mencoba untuk melaksanakan pembelajaran speaking khususnya pada mata pelajaran bahasa Inggris dengan menggunakan interactive learning. Selain menambah wawasan tentang interactive learning juga dapat meningkatkan motivasi siswa dalam belajar bahasa Iggris.

\section{DAFTAR PUSTAKA}

Abidin, Yunus. (2011). Teori Dan Implementasi Pembelajaran Bahasa. Hzaa Press

Adishara Dwi Arlini. (2010). Penerapan Role Playing dalam Pembelajaran Speaking Kelas IV SD. Skripsi. Universitas Pendidikan Indonesia kampus Cibiru: Tidak diterbitkan.

Basrowi dan Suwandi. (2008). Prosedur Penelitian Tindakan Kelas. Bogor: Ghalia Indonesia

BNSP. (2006). Standar Isi Bahasa Indonesia. Jakarta: BNSP

Brown, H. Douglas. (2001). Teaching By Principles An Interactive Approach To Language Pedagogy (second ed.). Longman: San Francisco State University.
Ellis, Gail and Brewster, Jean. (2002). The Primary English Teacher's Guide. London: Penguin English Tarigan, H. Guntur. (2009).Metodologi Pengajaran Bahasa 1. Bandung: Angkasa

Halliwell, Susan. (1992). Teaching English In The Primary School. London: Longman

Herrell, Adriene and Jordan, Michael. (2004). Fifty Strategies For Teaching English LanguageLearners. New Jersey: Pearson Education Izzan, Ahmad. (2010). Metodologi Pembelajaran Bahasa Inggris. Bandung: Humaniora

Linse. T, Caroline and Nunan David. (2005). Practical English Language Teaching Young Learners. Nort America: McGraw-Hill.

Moleong, J. Lexy. (2002). Metodologi Penelitian Kualitatif. Bandung: PT. Remaja Rosdakarya.

Mukarto. (2007). Grow With English an English Course For Elementary School Student Book 5. Jakarta: Erlangga

Mulyasa, H. E. (2008). Implementasi Kurikulum Tingkat Satuan Pendidikan. Jakarta: Bumi Aksara

Nurgiyantoro, Burhan. (2010). Penilaian Pembelajaran Bahasa Berbasis Kompetensi. Yogyakarta:BPFEYogyakarta

Permadi. Dadi, Suryana. Nanan. (2000). Pendekatan Metode, Tehnik Dan Model Pembelajaran Bahasa Inggris Di SD dan MI Sesuai Penyempurnaan/Penyusuaian Kurikulum Mulok Bahasa Inggris. Jawa Barat: PT. Sarana Panca Karya Nusa 
Phillips, sarah. (2004). Young Learners. New York: Oxford University Press

Prendiville, Francis and Toye, Nigel. (2007). Speaking And Listening Through Drama. 7-11[online]. Tersedia di: http://www.gigapedia.com[16 Maret 2011]

Resmini, novi., Djuanda, dkk. (2006). Pembinaan dan Pengembangan Pembelajaran Bahasa dan Sastra Indonesia. Bandung: UPI PRESS

Richards, C. Jack and Rodgers, S. Theodore. (2006). Approaches And Method In Language Teaching (second ed.). New York: Cambridge university press

Sardiman. (2010). Interaksi Motivasi \& Belajar Mengajar. Jakarta: PT. Raja Grafindo Persada

Silberman, L. Melvin. (2011). Interacive Learning 101 Cara Belajar Siswa Aktif. Bandung: Nusamedia

Sudjana, N. (2010). Penilaian Hasil Proses Belajar Mengajar. Bandung: Rosdakarya

Sugiyono. (2008). Metode Penelitian Pendidikan (Pendekatan kuantitatif, kualitatif, dan R\&D). Bandung: Alfabeta

Suryanto, dkk. (1997). Pengenalan Penelitian Tindakan Kelas (PTK). Yogyakarta: IKIP Yogyakarta Susilo, Herawati. Dkk. (2008). Penelitian Tindakan Kelas sebagai sarana
Pengembangan Keprofesionalan Guru Dan calon Guru. Malang: Bayumedia Publishing

Sutino. (2011). Peningkatan

Keterampilan Berbicara Dengan Menggunakan Metode Role Playing Pada Siswa kelas V SDN Pandak I Sidoharjo sragen Tahun Ajaran 2010/2011 [online]. Tersedia di: http://digilib.fkip.uns.ac.id/../skripsi. php[03 Mei 2011]

Suyanto, K.E. Kasihani. (2010). English For Young Learners. Jakarta: PT. Bumi Aksara Teacher Creative Corner. (2010). Metode Pembelajaran Bahasa Inggris (online). Tersedia di: http://baliteacher.blogspot.com/2010 /02/metode-pembelajaran-bahasainggris-sd.html[08 Desember 2010]

Oxford dictionary. (2005). Oxford learners pocket dictionary. Oxford Newyork.

Tuti. (2009). Language teaching [online]. Tersedia di: e-refleksi.ykedu.org/date-list-refleksi[01 Januari 2011]

Waluyo. J, Herman. (2001). Drama: Teori dan Pembelajarannya. Yoggyakarta: PT. Handita graham widya

Zipes, Jack. (2004). Speaking Out Story Telling And creative Drama For children [online]. Tersedia di: http://www.gigapedia.com[16 Maret 2011] 